\title{
PEMETAAN POTENSI MUSCULOSKLETAL DISORDERS (MSDS) PADA AKTIVITAS MANUAL MATERIAL HANDLING (MMH) KELAPA SAWIT
}

\author{
Roberta Zulfhi Surya \\ Program Studi Teknik Industri, Universitas Islam Indragri, Riau \\ email: robertazulfhi@yahoo.co.id
}

Received: December 14, 2016; Accepted: January 9, 2017

\begin{abstract}
ABSTRAK
Kelapa sawit (Elaeis) adalah tumbuhan industri penting penghasil minyak masak, minyak industri, maupun bahan bakar (biodiesel) sehingga bisnis kelapa sawit saat ini menjadi primadona. Aktivitas kerja di perkebunan kelapa sawit khususnya pekerjaan buruh bongkar muat yang berpotensi terjadinya Musculoskletal Disorders (MSDs). Aktivitas Manual Material Handling (MMH) kelapa sawit berpotensi menimbulkan Musculoskletal Disorders (MSDs) pada (1) leher bagian atas; (2) leher bagian bawah; (3)bahu kiri; (4) bahu kanan; (5) punggung; (6) lengan atas kanan; (7) lengan bawah kiri; (8) lengan bawah kanan; (9) pergelangan tangan kiri; (10) pergelangan tangan kanan; (11) tangan kiri; dan (12) tangan kanan. Hal ini disebabkan 12 bagian tubuh ini bersentuhan langsung dengan aktivitas tersebut. Penyebab primer Musculoskletal Disorders (MSDs) adalah sikap kerja tidak alamiah dan penegangan otot yang berlebihan yang bermula dari desain sistem kerja yang dirancang tidak sesuai dengan keterbatasan pekerja
\end{abstract}

Kata Kunci: Kelapa Sawit, Musculoskletal Disorders, Manual Material Handling

\begin{abstract}
Palm oil (Elaeis) is an important industrial plants producing cooking oil, industrial oil, and fuel (biodiesel) as the palm oil business is currently exceptional. Work activities in palm oil plantations, especially, loading and unloading are potentially causing Musculoskletal Disorders (MSDs). Manual Materials Handling $(M M H)$ activities in palm oil business potentially occurs MSDs at (1) the upper neck; (2) the lower neck; (3) the left shoulder; (4) the right shoulder; (5) the backs; (6) on the right arm; (7) under the left arm; (8) the right forearm; (9) the left wrist; (10) the right wrist; (11) the left hand; and (12) the right hand. MSDs happens due to these 12 body parts are in direct contact with the activities. The primary cause of MSDs is unnatural working attitude and excessive muscle tension began from the design of a working system that is designed not in accordance with the workers' limitations.
\end{abstract}

Keywords: Palm Oil, Musculoskletal Disorders, Manual Material Handling

\section{PENDAhuluan}

Kelapa sawit (Elaeis) adalah tumbuhan industri penting penghasil minyak masak, minyak industri, maupun bahan bakar (biodiesel). Perkebunannya menghasilkan keuntungan besar sehingga banyak hutan dan perkebunan lama dikonversi menjadi perkebunan kelapa sawit. Indonesia adalah penghasil minyak kelapa sawit terbesar di dunia. Di Indonesia penyebarannya di daerah Aceh, pantai timur Sumatra, Jawa, dan Sulawesi. Hingga saat ini aktivitas kerja di perkebunan kelapa sawit khususnya aktivitas bongkar-muat masih dilakukan secara manual yang mengandalkan tenaga manusia serta penggunaan alat dan metode kerja yang tidak memperhatikan keterbatasan manusia (Surya dan Gasali, 2014). Kondisi ini tentu saja berpotensi untuk menimbulkan permasalahan khususnya Musculoskletal Disorders (MSDs) terhadap pekerja buruh bongkarmuat. Sampai saat ini belum ada data yang tercatat dengan lengkap khususnya 
mengenai gangguan MSDs yang dialami oleh pekerja buruh bongkar muat sawit sebagai dampak dari pekerjaannya. Disamping itu, dengan belum diketahuinya tingkat risiko pekerjaan buruh bongkar muat dan permasalahan lain yang terkait dengan keluhan MSDs pada pekerja buruh bongkar muat mendorong penulis untuk meneliti mengenai alat bongkar muat yang digunakan para buruh tersebut dan hubungannya dengan keluhan MSDs (Hendra, 2009).

Manual Material Handling (MMH) kelapa sawit adalah pemindahan material dilakukan dengan alat bantu yang menggunakan energi manusia. Kemampuan manusia sangat berpengaruh untuk dapat menunjang penggunaan alat. Penggunaan alat dapat memberikan hasil optimal maka diperlukan adanya perbaikan alat-alat penunjang sesuai dengan postur tubuh dan akibat yang ditimbulkan terhadap tubuh. Pada proses pemindahan material kelapa sawit menggunakan Hook-T, operator berkerja dengan posisi kerja yang bermacam-macam. Posisi kerja ini akan berpengaruh terhadap kemungkinan terjadinya nyeri pada bagian tubuh tertentu. Dimensi dan bentuk tojok akan berpengaruh pada efektifitas dan kenyamanan dari para pengguna tojok tersebut. Aktivitas yang dilakukan untuk menggunakan tojok meliputi kombinasi antara aktivitas mengangkat dan mendorong. Kedua aktivitas dalam penggunaan alat ini akan berpengaruh besar terhadap resiko cedera musculoskeletal pada bagian tertentu.

Tojok sawit (Hook-T) merupakan alat angkat material pada area perkebunan, pertanian, perindustrian dan lain sebagainya. Jika ditinjau dari definisinya tojok adalah alat angkat yang didorong dengan tangan, memiliki tangkai seperti huruf $\mathrm{T}$ dan digunakan oleh satu orang operator melalui handle. Mengingat kepraktisan alat ini telah menjadikannya sebagai salah satu alat angkat yang sangat penting untuk menunjang aktivitas produksi. Sejalan dengan hal tersebut telah banyak pengembangan yang dilakukan terhadap sistem tojok.
Mengacu kepada sistem Hook-T konvensional, proses bongkar muat material merupakan bagian aktivitas yang menyulitkan bagi operator karena memerlukan banyak tenaga dan seringnya operator kehilangan keseimbangan waktu proses pemuatan dilakukan. Berdasarkan kondisi tersebut maka pada penelitian ini peneliti mencoba meneliti perbaikan terhadap Hook- $T$ yang dapat meringankan beban yang diterima oleh operator saat proses bongkar muat disamping untuk meningkatkan kestabilan waktu proses bongkar muat dilakukan (Rajuli, 2014). Penelitian ini berusaha memetakan potensipotensi terjadinya Musculoskletal Disorders (MSDs) pada aktivitas Manual Material Handling (MMH) sehingga diperoleh data dan informasi guna menciptakan sistem kerja yang ergonomis dan berkelanjutan.

\section{LANDASAN TEORI}

\subsection{Keluhan Muskuloskeletal}

Sistem Musculoskletal adalah sistem otot rangka atau otot yang melekat pada tulang yang terdiri atas otot-otot serat lintang yang sifat gerakannya dapat diatur (voluter). Kerja otot statis terjadi pada aktivitas mengangkat, menyangga, mendorong, menarik dan menurunkan beban ( otot lengan, bahu, pinggang dan punggung), sedangkan kerja otot dinamis terjadi pada aktivitas mengangkut, mendorong, dan menarik seperti; otot-otot bagian bawah. Sikap paksa sewaktu bekerja dan berlangsung lama dapat menyebabkan adanya beban pada sistem muskuloskeletal dan efek negatif pada kesehatan (Santoso, 2004).

Keluhan muskuloskeletal adalah keluhan pada bagian otot skeletal yang dirasakan oleh seseorang mulai dari keluhan sangat ringan sampai sangat sakit. Apabila otot menerima beban statis secara berulang dan dalam waktu yang lama, akan dapat menyebabkan keluhan berupa kerusakan pada sendi, ligamen dan tendon. Keluhan hingga kerusakan ini biasanya diistilahkan dengan keluhan musculoskeletal disorders atau cedera pada sistem muskuloskeletal. Secara garis besar keluhan otot dapat 
dikelompokkan menjadi dua (Tarwaka dkk., 2004) antara lain:

1. Keluhan sementara (reversible)

Keluhan sementara yaitu keluhan otot yang terjadi pada saat otot menerima beban statis, namun demikian keluhan tersebut akan segera hilang apabila pembebanan dihentikan.

2. Keluhan menetap (persistent)

Keluhan menetap yaitu keluhan otot yang bersifat menetap. Walaupun pembebanan kerja telah dihentikan, namun rasa sakit pada otot masih terus berlanjut.

Hasil studi menunjukkan bahwa bagian otot yang sering dikeluhkan adalah otot rangka (skeletal) yang meliputi otot leher, bahu, lengan, tangan, jari, punggung, pinggang dan otot-otot bagian bawah. Keluhan otot skeletal pada umumnya terjadi karena kontraksi otot yang berlebihan akibat pemberian beban kerja yang terlalu berat dengan durasi pembebanan yang panjang. Menurut (Peter, 2000) menjelaskan bahwa terdapat beberapa faktor yang dapat menyebabkan terjadinya keluhan Musculoskletal, yaitu:

1. Penegangan Otot yang Berlebihan

Penegangan otot yang berlebihan pada umumnya sering dikeluhkan oleh pekerja dimana aktivitas kerjanya menuntut pengerahan tenaga yang besar seperti aktivitas mengangkat, mendorong, menarik dan menahan beban yang berat. Peregangan otot yang berlebihan ini terjadi karena pengerahan tenaga yang diperlukan melampaui kekuatan optimum otot. Apabila hal serupa sering dilakukan, maka dapat mempertinggi resiko terjadinya keluhan otot, bahkan dapat menyebabkan terjadinya cedera otot skeleletal.

2. Aktivitas Berulang

Aktivitas berulang adalah pekerjaan yang dilakukan secara terus-menerus seperti pekerjaan mencangkul, membelah kayu besar, angkat-angkut dan lain-lain. Keluhan otot terjadi karena otot menerima tekanan akibat beban kerja secara terus-menerus tanpa memperoleh kesempatan untuk relaksasi.
3. Sikap Kerja Tidak Alamiah

Sikap kerja tidak alamiah adalah sikap kerja yang menyebabkan posisi bagian tubuh bergerak menjauhi posisi alamiah misalnya pergerakan tangan terangkat, punggung terlalu membungkuk, kepala terangkat dan sebagainya. Semakin jauh posisi bagian tubuh dari pusat gravitasi tubuh, maka akan semakin tinggi pula resiko terjadinya keluhan otot skeletal. Sikap kerja tidak alamiah ini pada umumnya karena karakteristik tuntutan tugas, alat kerja dan stasiun kerja tidak sesuai dengan kemampuan dan keterbatasan pekerja.

4. Faktor penyebab sekunder terjadinya keluhan muskuloskeletal, yaitu:

a. Tekanan

Terjadinya tekanan langsung pada jaringan otot yang lunak. Sebagai contoh, pada saat tangan harus memegang alat, maka jaringan otot tangan yang lunak akan menerima tekanan langsung dari pegangan alat, dan apabila hal ini sering terjadi, dapat menyebabkan rasa nyeri otot yang menetap.

b. Getaran

Getaran dengan frekuensi tinggi akan menyebabkan kontraksi otot bertambah. Kontraksi statis ini menyebabkan peredaran darah tidak lancar, penimbunan asam laktat meningkat dan akhirnya timbul rasa nyeri otot.

c. Mikroklimat

Paparan suhu dingin yang berlebihan dapat menurunkan kelincahan, kepekaan dan kekuatan pekerja sehingga gerakan pekerja menjadi lamban, sulit bergerak yang disertai dengan menurunnya kekuatan otot, demikian juga dengan paparan udara yang panas. Beda suhu lingkungan dengan suhu tubuh yang terlampau besar menyebabkan sebagian energi yang ada dalam tubuh akan termanfaatkan oleh tubuh untuk beradaptasi dengan lingkungan tersebut. Apabila hal ini tidak diimbangi dengan pasokan energi yang cukup, maka akan terjadi 
kekurangan suplai energi ke otot, akibatnya peredaran darah kurang lancar, suplai oksigen ke otot menurun, proses metabolisme karbohidrat terhambat dan terjadi penimbunan asam laktat yang dapat menimbulkan rasa nyeri otot.

5. Penyebab kombinasi.

Selain faktor-faktor yang telah disebutkan di atas, beberapa ahli menjelaskan bahwa faktor individu seperti umur, jenis kelamin, kebiasaan merokok, aktivitas fisik, kekuatan fisik dan ukuran tubuh juga dapat menjadi penyebab terjadinya keluhan otot skeletal.

\subsection{Batasan Beban yang Boleh Diangkat} Mengurangi cedera otot bagian belakang seperti; pinggang dan punggung pada aktivitas angkat dan angkut maka harus dipertimbangkan kriteria angkat baik secara fisiologik maupun psikofisik. Batasan angkat didasarkan pada perhitungan risiko cedera pada discus lumbar-5 dan sacral-1 (L5/S1), maka batas angkat maksimum yang direkomendasikan adalah sebesar 3,4 Kn sebagai gaya tekan pada discus tersebut. Di antara ruas-ruas tulang belakang terdapat discus yang berfungsi sebagai peredam bila ada gesekan atau benturan.Cedera atau nyeri sering terjadi pada discus (intervertebrae disc) yang berada di antara discus ke-4 dan ke-5 (L4/L5) atau terletak di antara lumbar ke-5 dan sacrum ke-1(L5/S1).Ilustrasi dari discus L4/L5 dan L5/S1 dapat dicermati pada Gambar 1. Batasan angkat secara fisiologik dilakukan dengan cara mempertimbangkan rata-rata beban metabolisme dari aktivitas angkat yang berulang-ulang (repetitive lifting), dapat ditentukan dari jumlah kebutuhan oksigen.

Kelelahan kerja yang terjadi akibat aktivitas angkat yang berulang-ulang akan meningkatkan risiko rasa nyeri pada tulang belakang. Selanjutnya batasan angkat secara psikofisik pada penilaian subjektif pekerja mempertimbangkan sejauh mana individu merasa mampu mengangkat beban maksimum (Bridger, 1995). Secara umum beban angkat perseorangan yang direkomendasikan oleh International Labor Organisation (ILO) untuk pria dan wanita dicermati pada Tabel 2.1.

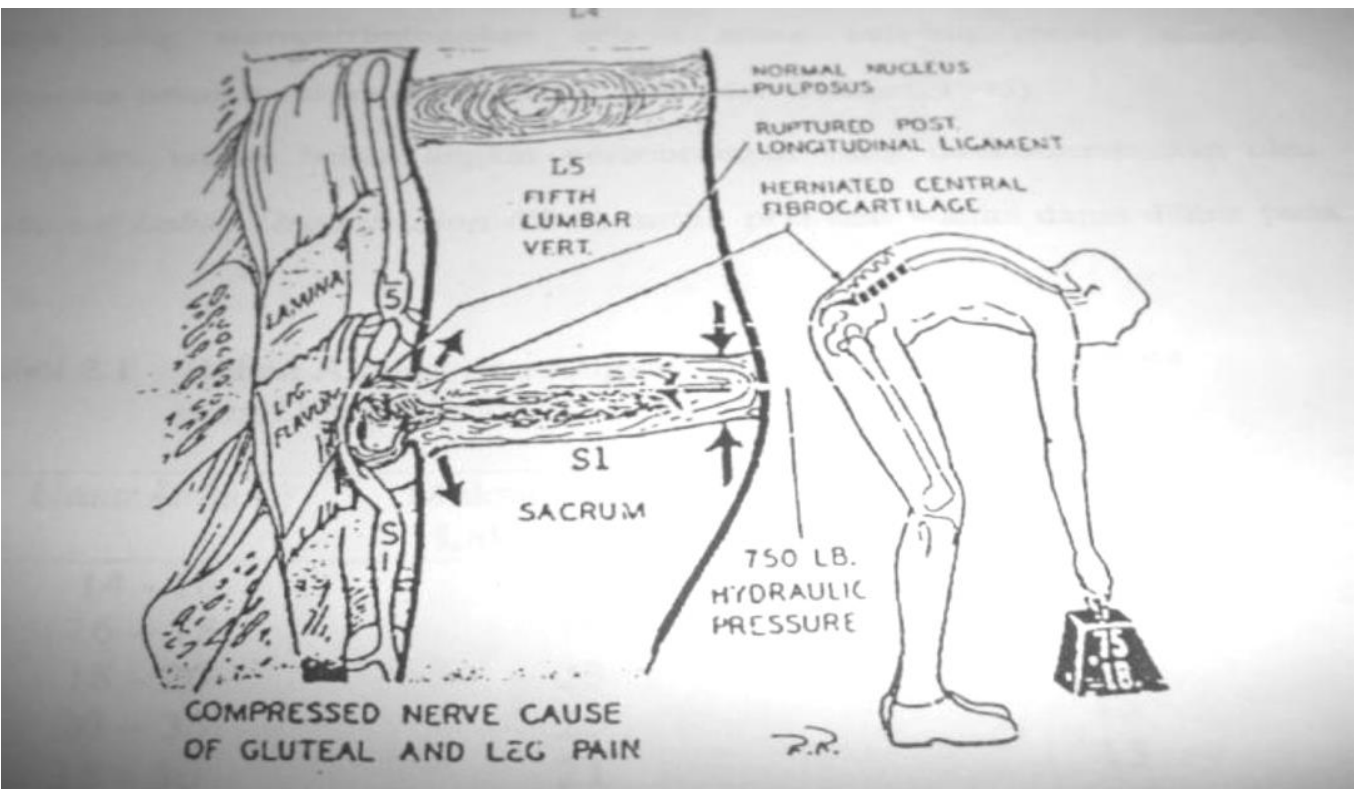

Gambar 1. Lokasi Vertebral Lumbalis Sakrallis (discus L4/L5 dan L5/S1). Kelainan Herniasi Akibat Mengangkat Terdapat pada L5/S1.

Sumber: Bridger (1995) 
Tabel 1. Beban Angkat dan Angkut bagi Laki-laki dan Wanita yang Direkomendasi Umur (tahun) Maksimum untuk Laki-laki (Kg) Maksimum untuk Wanita (Kg)

\begin{tabular}{ccc}
\hline $14-16$ & 15 & 10 \\
$16-18$ & 19 & 12 \\
$18-20$ & 23 & 14 \\
$20-35$ & 25 & 15 \\
$35-50$ & 21 & 13 \\
$>50$ & 16 & 10 \\
\hline
\end{tabular}

Sumber: Pheasant (1991)

Penjelasan tersebut dapat disimpulkan bahwa cara mengangkat dan mengangkut, beban yang diangkat dan diangkut, ketinggian landasan mengangkat dan jarak angkut berpengaruh terhadap beban kerja, kelelahan dan produktivitas kerja. Faktor tugas pekerjaan, lingkungan kerja juga dapat mempengaruhi performansi kerja.

\section{METODE}

\subsection{Langkah Penelitian}

1. Penentuan sampel sesuai kriteria inklusi;

2. Membiarkan buruh bekerja seperti biasa;

3. Mengobservasi keluhan-keluhan Musculoskletal buruh dengan cara wawancara sesuai Kuesioner Nordic Body Map;

4. Menganalisa hasil jawaban buruh bongkar muat kelapa sawit;

5. Memberikan data dan informasi keluhan Musculoskletal untuk dijadikan dasar perbaikan sistem kerja dan penelitian selanjutnya.

\subsection{Tempat}

Lokasi penelitian ini dilakukan disentra pembelian kelapa sawit yang ada di Desa Pulau Palas Kecamatan Tembilahan Hulu Kabupaten Indragiri Hilir Riau.

\subsection{Populasi dan Sampel}

Populasi ialah seluruh subjek penelitian yakni semua buruh atau pekerja di sentra pembelian kelapa sawit yang berada di Desa Pulau Palas Kecamatan Tembilahan Hulu Kabupaten Indragiri Hilir Riau.

Sampel adalah sebagian dari populasi yang di teliti tetapi sampel penelitian yang dilakukan merupakan sampel jenuh dengan jumlah populasi 14orang, maka semua buruh atau pekerja sentra pembelian kelapa sawit yang berada di Desa Pulau Palas Kecamatan Tembilahan Hulu Kabupaten Indragiri Hilir di jadikan sampel penelitian yang memenuhi kreteria inklusi sebagai berikut:

1. Usia berada antara 20-35 tahun;

2. Dalam kondisi sehat (tidak mengalami cacat fisik dan mental);

3. Jenis Kelamin Laki-laki.

4. Sudah bekerja sebagai buruh bongkar muat minimal 1 (satu) tahun;

5. Bersedia sebagai objek penelitian sampai selesai.

\subsection{Nordic Body Map}

Kelelahan otot merupakan fenomena fisiologi dapat diukur secara langsung dengan Electromyography (EMG) untuk mendeteksi penyebab terjadinya kelelahan, sedangkan metode pengukuran secara tidak langsung berupa penilaian subjektif pada pekerja dengan menanyai dan menunjukan diagram tubuh atau kuesioner untuk menentukan lokasi kelelahan atau gangguan muskuloskeletal disebut Nordic Body Map. Kuesioner Nordic Body Map dipilih sebagai alat ukur untuk menilai kelelahan otot berupa gangguan muskuloskeletal dengan alasan digunakan metode ini karena mudah, murah dan cukup reliabel. Penerapan di lapangan dilakukan penjelasan sederhana kepada pekerja. Interpretasi hasil jawaban responden untuk rata-rata skor 1 tidak saikit; rata-rata skor 1,1-2 digolongkan agak sakit, rata-rata skor 2,1-3 digolongkan sakit dan rata-rata skor 3,1-4 digolongkan sangat sakit. 


\section{HASIL DAN PEMBAHASAN}

\subsection{Profil Sampel}

Total buruh pada Sentra Pembelian kelapa sawit di Desa Pulau Palas Kecamatan Tembilahan Hulu Kabupaten Indragiri Hilir Riau adalah 23 orang dimana 9 diantaranya tidak termasuk dalam kriteria dan 14 orang buruh termasuk dalam kriteria inklusi. Sampel semuanya berjenis kelamin laki-laki dan tidak dalam keadaan sakit. Rata-rata usia sampel adalah $28 \pm 2,10,7$ tahun dan telah bekerja sebagai buruh bongkar muat kelapa sawit $2 \pm 0,7$ tahun

\subsection{Keluhan Subjektif}

Berdasarkan jawaban kuisioner 14 orang sampel yang berada di sentra pembelian kelapa sawit yang berada di Desa Pulau

Palas Kecamatan Tembilahan Hulu Kabupaten Indragiri Hilir Riau keluhankeluhan subjektif dapat dilihat pada Tabel 2 di bawah ini.

Tabel 2. Keluhan Subjektif Pekerja

\begin{tabular}{|c|c|c|}
\hline \multicolumn{2}{|r|}{ Keluhan Subjektif } & $\begin{array}{c}\text { Rata-Rata }(\bar{x}) \\
\text { Sebelum }\end{array}$ \\
\hline 1 & Sakit/Kaku di leher bagian atas & 2.6 \\
\hline 2 & Sakit/Kaku di leher bagian bawah & 2.5 \\
\hline 3 & Sakit di bahu kiri & 2.8 \\
\hline 4 & Sakit di bahu kanan & 2.6 \\
\hline 5 & Sakit pada lengan atas kiri & 2.0 \\
\hline 6 & Sakit di punggung & 2.6 \\
\hline 7 & Sakit pada lengan atas kanan & 2.1 \\
\hline 8 & Sakit pada pinggang & 1.7 \\
\hline 9 & Sakit pada bawah pinggang & 1.0 \\
\hline 10 & Sakit pada bokong & 1.0 \\
\hline 11 & Sakit pada siku kiri & 1.5 \\
\hline 12 & Sakit pada siku kanan & 1.4 \\
\hline 13 & Sakit pada lengan bawah kiri & 2.4 \\
\hline 14 & Sakit pada lengan bawah kanan & 2.3 \\
\hline 15 & Sakit pada pergelangan tangan kiri & 2.4 \\
\hline 16 & Sakit pada pergelangan tangan kanan & 2.3 \\
\hline 17 & Sakit pada tangan kiri & 3.0 \\
\hline 18 & Sakit pada tangan kanan & 2.9 \\
\hline 19 & Sakit pada paha kiri & 1.0 \\
\hline 20 & Sakit pada paha kanan & 1.0 \\
\hline 21 & Sakit pada lutut kiri & 1.1 \\
\hline 22 & Sakit pada lutut kanan & 1.2 \\
\hline 23 & Sakit pada betis kiri & 1.4 \\
\hline 24 & Sakit pada betis kanan & 1.3 \\
\hline 25 & Sakit pada pergelangan kaki kiri & 1.8 \\
\hline 26 & Sakit pada pergelangan kaki kanan & 1.5 \\
\hline 27 & Sakit pada telapak kaki kiri & 1.0 \\
\hline 28 & Sakit pada telapak kaki kanan & 1.0 \\
\hline
\end{tabular}


1. Tidak sakit

Golongan keluhan subjektif tidak sakit adalah sebagai berikut:

a. Sakit pada bawah pinggang

b. Sakit pada bokong

c. Sakit pada paha kiri

d. Sakit pada paha kanan

e. Sakit pada telapak kaki kiri

f. Sakit pada telapak kaki kanan

2. Agak Sakit

Golongan keluhan subjektif agak sakit adalah sebagai berikut:
a. Sakit pada lengan atas kiri
b. Sakit pada pinggang
c. Sakit pada siku kiri
d. Sakit pada siku kanan
e. Sakit pada lutut kiri
f. Sakit pada lutut kanan
g. Sakit pada betis kiri
h. Sakit pada betis kanan
i. Sakit pada pergelangan kaki kiri
j. Sakit pada pergelangan kaki kanan

3. Sakit

Golongan keluhan subjektif sakit adalah sebagai berikut:

a. Sakit/Kaku di leher bagian atas

b. Sakit/Kaku di leher bagian bawah c. Sakit di bahu kiri

d. Sakit di bahu kanan

e. Sakit di punggung

f. Sakit pada lengan atas kanan

g. Sakit pada lengan bawah kiri

h. Sakit pada lengan bawah kanan

i. Sakit pada pergelangan tangan kiri

j. Sakit pada pergelangan tangan kanan

k. Sakit pada tangan kiri

1. Sakit pada tangan kanan

\subsection{Pembahasan}

Tingkatan rasa sakit berupa MSDs pada penelitian ini digolongkan menjadi 4 (empat) yaitu tidak sakit, agak sakit, sakit dan sangat sakit. Bagian tubuh yang tidak merasakan sakit yaitu bagian tubuh yang tidak terlibat lansung dalam aktivitas Manual Material Handling (MMH) kelapa sawit. Sementara keluhan subjektif yang merasakan agak sakit bagian tubuh ytang menopang proses yaitu betis, pergelangan kaki dan siku. Sedangkan yang tergolong dalam kategori sakit adalah bagian tubuh yang terlibat lansung seperti pada bagian tangan, punggung, bahu dan leher. Pada Gambar 2 di bawah ini ditunjukkan aktivitas Manual Material Handling (MMH) kelapa sawit.

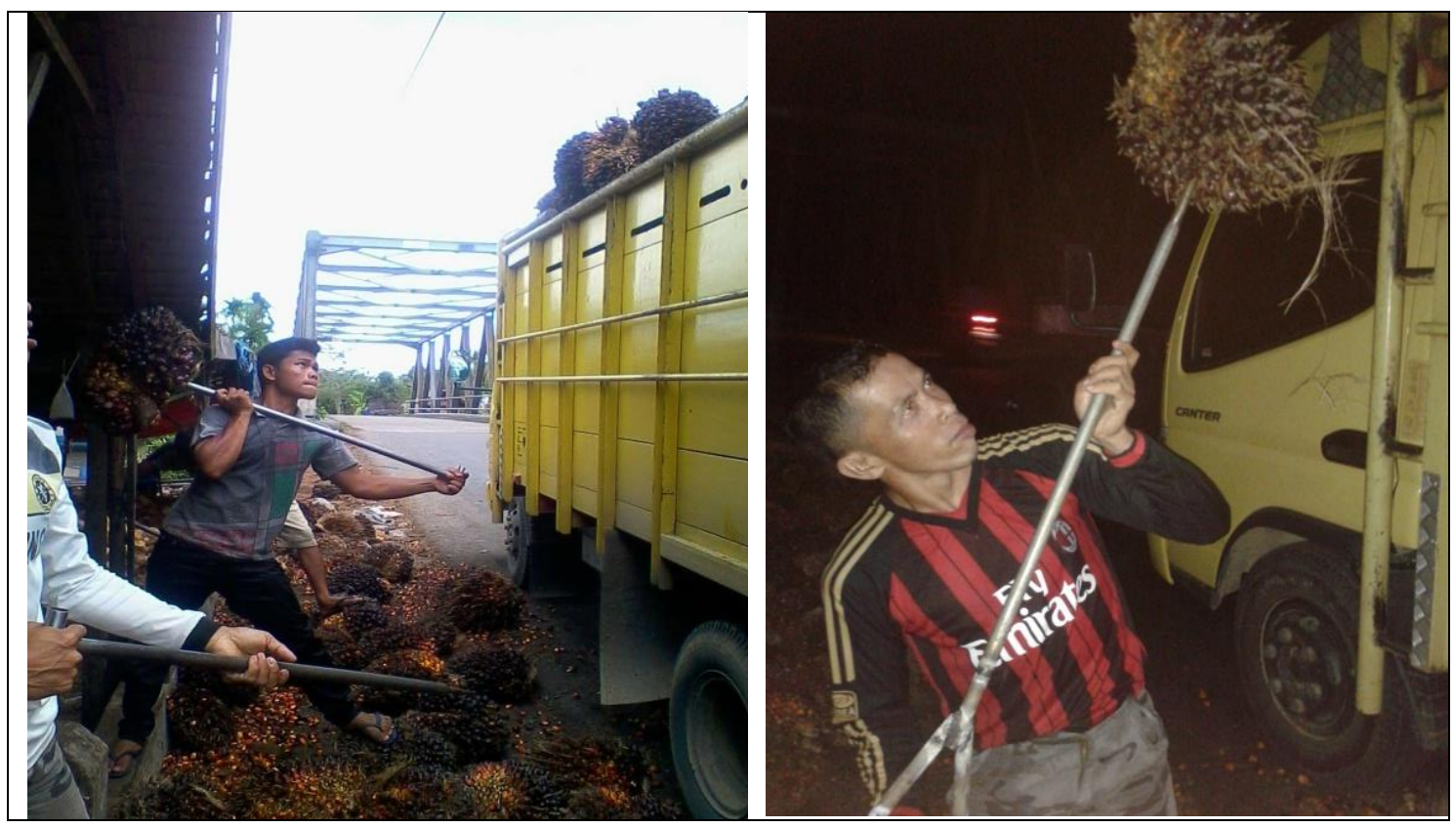

Gambar 2. Aktivitas Manual Material Handling (MMH) Kelapa Sawit 
Aktivitas Manual Material Handling (MMH) kelapa sawit memasukkan tandan buah sawit ke dalam truk ditambah dengan panjang gagang hook- $T$ tidak dirancang sesuai dengan antropometri pekerja akibatnya sering terjadi punggung terlalu membungkuk, kepala terangkat dan kaki menjinjit, hal ini merupakan posisi kerja tidak alamiah karenasemakin jauh posisi bagian tubuh dari pusat gravitasi tubuh, maka akan semakin tinggi pula resiko terjadinya keluhan otot skeletal.

Kisaran berat rata-rata tandan buah sawit antara $10-50 \quad \mathrm{~kg}$ membuat pekerja mengerahkan tenaga besar untuk memasukkan kedalam truk. Rajuli (2014) menjelaskan selain beban berat, aktivitas untuk memasukkan tandan buah sawit kedalam truk adalah gerakan berulang, biasanya lebih dari 10 gerakan per menit.

Peregangan otot yang berlebihan ini terjadi karena pengerahan tenaga yang diperlukan melampaui kekuatan optimum otot dimana nilai Maximum Acceptable Weight of Lift (MAWL) pekerja laki-laki Indonesia pada segmen bahu-jangkau 2 kali permenit adalah $12,3 \pm 0,68 \mathrm{~kg} ; 4$ kali permenit adalah $11,49 \pm 0,59 \mathrm{~kg}$; serta 8 kali permenit adalah $10,41 \pm 0,68 \mathrm{~kg}$ (Santoso, 2006). Apabila aktivitas buruh kelapa sawit pada kasus ini dikomparasikan dengan standar MAWL pekerja Indonesia, hal ini menunjukkan bahwa aktivitas tersebut sangat jauh dari standar ergonomi sehingga tidak heran jika sering terjadi Musculoskletal Disorders (MSDs) pada aktivitas tersebut.

\section{KESIMPULAN}

Aktivitas bongkar muat kelapa sawit hingga saat ini masih mengandalkan tenaga manusia dimana tenaga manusia dianggap lebih murah dan fleksibel. Gerakan berulang lebih dari 10 gerakan permenit serta berat tandan buah sawit yang mencapai $50 \mathrm{~kg}$ membuat aktivitas ini semakin tidak ergonomis. Aktivitas Manual Material Handling $(\mathrm{MMH})$ kelapa sawit berpotensi menimbulkan Musculoskletal Disorders (MSDs) pada (1) leher bagian atas; (2) leher bagian bawah; (3) bahu kiri; (4) bahu kanan; (5) punggung; (6) lengan atas kanan; (7) lengan bawah kiri; (8) lengan bawah kanan; (9) pergelangan tangan kiri; (10) pergelangan tangan kanan; (11) tangan kiri; dan (12) tangan kanan. Hal ini disebabkan 12 bagian tubuh ini bersentuhan lansung dengan aktivitas tersebut. Penyebab primer Musculoskletal Disorders (MSDs) adalah sikap kerja tidak alamiah dan penegangan otot yang berlebihan yang bermula dari desain sistem kerja yang dirancang tidak sesuai dengan keterbatasan pekerja dan bobot tandan buah segar yang dapat mencapai $50 \mathrm{~kg}$. Setelah diketahui potensipotensi Musculoskletal Disorders direkomendasikan penelitian selanjutnya untuk mengkaji Desain Model Diagnostik Resiko Ergonomi pada aktivitas bongkar muat kelapa sawit serta perancangan alat bantu dan metode kerja yang mempertimbangkan keterbatasan manusia.

\section{DAFTAR PUSTAKA}

1. Bridger, R.S. (1995). Introduction to Ergonomics. Singapore: McGraw-Hill. Inc.

2. Dewi, N.S. (2014). Desain Model Diagnostik Resiko Ergonomi Pada Pemanenan Kelapa Sawit Secara Manual. Tesis Program Magister Teknik Mesin Pertanian dan Pangan. Institut Pertanian Bogor.

3. Hendra. (2009). "Resiko Ergonomi dan Keluhan Musculoskletal Disorders (MSDs) pada Pekerja Panen Kelapa Sawit”. Jurnal Fakultas Kesehatan Masyarakat Universitas Indonesia.

4. Peter, V. (2000). Musculoskletal Disorders (MSDs), (citid2013 june 12). Available from: http://www.csao.org/uploadfiles/magazi ne/vol.11 no3/muscolo.html.

5. Pheasant. (1991). Ergonomic Work and Health. Aspen Publisher.

6. Rajuli (2014). Redesign Hook-T Muat Sawit menggunakan Metode Quality Function Deployment (QFD). Skripsi Teknik Industri Universitas Islam Indragiri.

7. Santoso, D. (2006). "Kapasitas Angkat Beban untuk Pekerja Indonesia". Jurnal Teknik Industri, Vol.8 No.2. 
ISSN: 1979-1720 Journal of Industrial Engineering and Management Systems

Vol. 10, No. 1, February 2017

8. Santoso, G. (2004). Ergonomi Manusia, Lingkungan dan Peralatan. Jakarta: Prestasi Pustaka Publisher.

9. Surya R.Z. dan Gasali, M. (2014). "Pemanfaatan Ergonomi pada Kegiatan Pascapanen Kelapa Sawit Untuk Mengurangi Keluhan Mosculuskeletal Petani”. Jurnal Statistika, Vol. 14 No. 2.

10.Tarwaka., Bakri, S.H.A. dan Sudiajeng, L. (2004). Ergonomi untuk Keselamatan, Kesehatan Kerja, dan Produktivitas. Surakarta: UNIBA PRESS. 